\title{
E-counselling support during COVID-19 pandemic: analysis of learners' feedback
}

\author{
Anil K. Dimri \\ Regional Centre Chandigarh, Indira Gandhi National Open University, \\ New Delhi, India
}

\begin{abstract}
Purpose - This research study aimed to collect feedback from the learners on the usefulness and effectiveness of the online counselling sessions organised during COVID-19 lockdown through online platforms to provide academic support to the learners.

Design/methodology/approach - The link of a questionnaire designed in a Google Form sent to IGNOU learners of the January 2020 session enrolled under the jurisdiction of IGNOU Regional Centre (RC) Chandigarh through email as well as SMSs. Total responses received were 487, out of which 445 responses were complete, roughly $8 \%$ of the total registered learners during the January 2020 session. The questionnaire contained questions on a cross-section of online counselling issues, besides questions on the learners' profile.
\end{abstract}

Findings - Majority of the learners were satisfied with the input provided while organising online counselling sessions during COVID-19 lockdown in India. A significant proportion of learners $(88 \%)$ used smartphones for attending counselling sessions. Facebook page of the RC rated as a relatively better option than other online platforms. However, more than $50 \%$ of learners faced Internet connection problems and found them a significant hurdle for smooth viewing of online counselling sessions. The proportion of learners who encountered difficulties in handling electronic devices was insignificant. The learner's feedback on many attributes such as usefulness and effectiveness of the online counselling sessions, interaction with the academic counsellors, e-content used in the counselling was significantly positive. A significant proportion of the learners have reported that face to face counselling could be replaced with online sessions in future, considering its flexibility in terms of place and schedule of learning and availability of recording of such sessions.

Research limitations/implications - The research study was conducted under Chandigarh region of IGNOU which has a predominantly urban population. Thus the results of the study are limited to Chandigarh region and the region with similar socio-economic settings. This certainly limits the scope of the study.

Practical implications - The study certainly provides valuable feedback to the ODL policymakers to consider replacing face-to-face counselling with an online mode in a phased manner. Online counselling options will be highly cost-effective, easily manageable, and provide flexibility for learners and resource persons, resulting in addressing learners' non-attendance related issues in the face-to-face counselling sessions.

Social implications - In the analysis of our finding it is clearly stated that the Internet connectivity and availability of electronic devices is an important issue to provide online counselling support to socially and economically disadvantaged groups. Therefore, the research study also identifies such social issues as a major challenge for providing online counselling support to the learners.

Originality/value - This is an original empirical research study and data collected is used in the analysis for the first time. This analysis is based on the feedback gathered from the learners registered at IGNOU RC Chandigarh during the January 2020 session. The data and derived results not used in any other study.

Keywords Open and distance learning, Online education, Academic counsellor, E-counselling

Paper type Research paper

(C) Anil K. Dimri. Published in Asian Association of Open Universities Journal. Published by Emerald Publishing Limited. This article is published under the Creative Commons Attribution (CC BY 4.0) licence. Anyone may reproduce, distribute, translate and create derivative works of this article (for both commercial and non-commercial purposes), subject to full attribution to the original publication and authors. The full terms of this licence may be seen at http://creativecommons.org/licences/by/4.0/legalcode
E-counselling support during COVID-19 pandemic

Received 4 November 2020 Revised 28 December 2020 16 January 2021

8 March 2021

16 April 2021

Accepted 6 May 2021
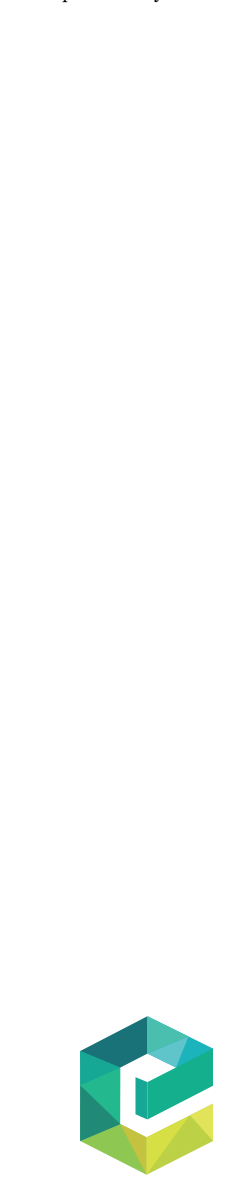

Asian Association of Open Universities Journa Vol. 16 No. 2, 2021 pp. $145-160$ e-ISSN: 2414-6994 p-ISSN: $1858-3431$ DOI 10.1108/AAOUJ-10-2020-0084 
AAOUJ

16,2

\section{Introduction}

The COVID-19 pandemic has impacted education systems globally, imposing formidable challenges to their smooth functioning, leading to a discontinuity in their operations. On the flip side, the pandemic's unprecedented situation has also compelled educational systems to respond with alternative mechanisms for providing teaching-learning support to the learners. The Indira Gandhi National Open University (IGNOU), with its national and international presence, proactively transitioned to adopt a blended approach from the ODL mode to effectively combat the pandemic situation and maintain the educational pursuits of its learners. The existing ODL methodologies of face-to-face(f2f) counselling, the telecast, broadcast and web-based techniques have facilitated the pedagogic shift to online and remote teaching approaches (Lynch, 2020).

The academic activities in IGNOU for the January 2020 session were likely to commence through its Learner Support Centres (LSCs) which are the interface between the university and the learners. The academics at the Regional Centres (RCs) were planning and scheduling induction meetings for new entrants. However, the planned meetings of the RCs had to postponed in compliance with the series of guidelines issued by the Ministry of Education (MOE), (erstwhile Ministry of Human Resources Development), Government of India (GOI), under the instructions given by the Ministry of Home Affairs (MHA) in conformity with the SOPs of World Health Organization (WHO) to deal with COVID-19 crisis. Thus, the declaration of a nationwide lockdown in India to combat the spread of the COVID-19 (coronavirus) outbreak put all activities, including learner support services, on hold. The operations of educational institutions were severely hampered and kept on suspension sine die. IGNOU also suspended all its activities, including f2f interaction with the learners, i.e. including induction meetings and theory and practical counselling, which are essential academic activities immediately after commencement of a session.

Learners' pursuit of learning was disturbed due to this sudden closure of educational institutions. Learners were quandary, anxious and restless about their academic calendar and further study progress in the university. In the prevailing unprecedented situation, it was likely that the sudden discontinuation of communication with the learners would increase anxiety and restlessness among them (Dimri, 2018). They would be anxiously waiting for the information from the university to pace their learning schedule. To restore the learners' confidence, some RCs played a pioneering role by adopting several innovative approaches to establish communication and provide academic support through online mode during the lockdown period. Accordingly, $\mathrm{RC}$ Chandigarh decided to conduct an online induction meeting using RC Facebook page, zoom, and Google meet platforms to sustain the learners' interest, thereby enforcing and improving the quality of learning (Olcott, 2020). A series of einduction meetings conducted to provide study-related information to the learners. The overwhelming response to the e-induction meetings encouraged the $\mathrm{RC}$ to take forward the scheduled plan for organising e-counselling sessions.

Several factors determine the learners' satisfaction level while pursuing online courses, including supportive learning activities (Chen, 2007; Lister, 2014). Other equally essential elements comprise continuous feedback to the learner's performance (Britto and Rush, 2013), regular two-way interaction (Roper, 2007) and constructive interaction with peers besides availability of quality content, proper assessment, computer and Internet self-efficacy (Anderson and Dron, 2011). It is argued that "learners often appreciated synchronous online courses" as they find it an effective means of communication with improved participation and course completion rates (Yamagata-Lynch, 2014). Online education also helps to build rapport with peers and instructor so that course-related activities are accomplished in time (Watts, 2016). The learners' academic issues resolved by having real-time interaction and discussion; therefore, online course delivery helps to build strong relationship provided a suitable learning environment is created (Figlio et al., 2013). 
This research paper attempts to critically analyse the learners' feedback for the January 2020 session under RC Chandigarh, where online counselling sessions organised using various online platforms. The conduct of e-counselling sessions also monitored to ensure that productive academic deliberation held. If the delivery of content in a particular session was not up to the expectation of learners, the engagement of such Academic Counsellor (ACs) reviewed and feedback provided for further improvement.

\section{Objectives of the study}

The research study's main objective was to assess the effectiveness of the e-counselling sessions organised during the lockdown period. The other objectives which the research study addressed are:

(1) Whether the content delivered through e-counselling sessions met the learners' studyrelated requirement?

(2) Do the academic counsellors explain the topics with clarity?

(3) Can online counselling sessions replace face to face counselling sessions?

(4) Whether the online counselling sessions were interactive?

\section{Literature review}

While examining the use of technology to provide academic support to the learners in UKOU, Tait (2014) argued that e-learning is considered the' next-generation education of distance education as it has been used widely by countries across the world. The author also analysed the dropout issues in distance education and e-learning and emphasised that the student support services should be "integrated with curriculum and assessment" to sustain learners' interest. The author further pointed out that if second-generation institutions are not ready to adjust with student support services methodology, the "new entrants to online learning will leapfrog their predecessors with an improved student experience".

Open and distance learning have witnessed several transitional phases, including the concept of "transactional distance, 'emphasising the tutors' role in supporting the learners (Moore, 1993). The use of ICT made interaction between learners and learners to tutor easy (Tait, 2004). The author further argued that the notion of constructivism influenced this notion". On the other hand, Thorpe (2002) opined clear cut conventional boundaries between learners' support and computer-mediated communication. She pointed out that computermediated communication is an integral part of the course content breaks down the "separation of learners support and teaching".

The digital divide and global access are the main concerns of many students, particularly in developing countries that do not have access to laptop and desktop (Lynch, 2020). Even if they had smartphones, they always worried about the amount of data likely to be consumed to attend Emergency Remote Teaching (ERT). He further argued that students' digital skill to learn online was also not visualised before enforcement of ERT. Therefore, the focus should be on developing "better infrastructure, policies for quality improvement, accessibility standards and strategic plans for continued accesses".

It envisaged that distance education is interdisciplinary and evolved with time and is slightly different from the ERT. Distance education is defined as the distance in time and space between learners and learning resources, "whereas ERT emphasises' on spatial distance" (Bozkurt and Sharma, 2020). On the other hand, it expresses that distance education facilitates' interactions between different parties and through different channels to let learners be more engaged in the learning process (Moore, 1989). The authors also emphasised that "when things go back to normal, people will not remember the educational content
E-counselling support during COVID-19 pandemic

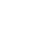

. 
AAOUJ

16,2

148

delivered, but they will remember how they felt, how we cared for them, and how we supported them" (Bozkurt and Sharma, 2020). Thus, ERT could be a means to establish communication with learners; it cannot substitute face-to-face classroom teaching. On the other hand, it emphasised (Golden, 2020) course delivery through ERT is a "temporary solution to the immediate problem" and cannot be considered distance teaching.

The majority of the respondents reported the usefulness of the availability of e-content for the preparation of assignments (Dimri, 2020). He further argued that the learners wellreceived support services provided during the lockdown. It helped them sustain their motivation and pursuit of learning despite having several problems such as non-availability of devices, uniform Internet speed, and partial e-content.

It emphasised (Hodges et al., 2020) that abrupt migration to online learning due to the COVID-19 crisis followed by lockdown has "disturbed the life of students, staff and faculty comfort". However, they argued that work with ERT would not be a continued priority; therefore, "asynchronous activities might be more reasonable than synchronous ones" (Clark et al., 2015). The authors further argued that "COVID-19 will soon be a memory, and once the faculty will return to normal teaching, they will forget ERT" (Bozkurt and Sharma, 2020). Thus, COVID-19 has posed challenges for the teachers, students, and staff and given opportunities for them to cope with suitable strategies to implement ERT in a similar situation.

Online learning has grown manifolds over some time due to the integration of technology (Reiser and Dempsey, 2012); moreover, it is "convenient than traditional education for the learners and instructors and provides many learners opportunities to take admission simultaneously". However, one of the major disadvantages of online education is the "separation of tutors and learners which prevents them from making a social connection with teachers and peers" (Moore and Kearsley, 2005). They further argued that the availability of "rich resources would help the learners to promote flexible social interaction with the teachers and the other learners. Thus, in addition to "cognitive factors, social factors are equally important for designing the online learning environment (Moore, 1989). Otherwise, the learners may feel a lack of immediacy in responses compared to f2f learning" (Mayer and Richard, 2012). They also argued that "social respect, social sharing, open mind, social identity and intimacy are also important factors for online learners" cognitive development.

Online education is an "emerging field that lies at the junction of distance education, human-computer interaction with Internet, instructional technology and cognitive science" (Gorge and Gaea, 2016). The authors further emphasised that online education is a "case of instructional alternative for on-campus learning and teaching and case of distance learning". Thus it is a convergence of technology with instruction scholarship of learning.

Although online education provided an opportunity to pursue quality education even to low-income students from developing countries, it has some issues to be addressed effectively. These include "adaptability, digital divide" (Bayrak et al., 2020), technical capability, time management, required communication skills, learning styles and lack of feedback on the performance'. The authors also pointed out that excessive "virtual engagement to attend the classes, undertake assignments, and over engagement in discussion forum" are some of the drawbacks of online education (Kurucay and Inan, 2017).

Online education initiatives initially started by the premier universities and institutions across the world, including Columbia University, Yale University, Stanford University, the University of Chicago, the London School of Economics (LSE) and the Massachusetts Institute of Technology (MIT) (Kriger, 2001; Woody, 1999). Nevertheless, it captured the world's attention due to its flexible characteristics, and OERs and MOOCs have now become a reality in the education world. Hence, it felt pertinent to obtain and analyse learners' feedback on the various aspects of online academic support. 


\section{Methodology}

Before organising online counselling/classes, the RC organised a meeting of Coordinators of Study Centres using the zoom platform. The objective was the identification of suitable ACs and the selection of courses for e-counselling sessions. A comprehensive schedule was prepared and communicated to the learners through email, SMSs and uploaded on the RC website. In courses selection, the learners' feedback obtained during the induction meetings and through the mail considered. Each day, 3-5 online counselling sessions organised across the various programmes and courses depending on the availability of ACs. The survey research method adopted to accomplish the present research study.

Sample: The sample of the study comprised learners registered for the January 2020 admission cycle. During the lockdown, 387 online counselling sessions were organised, which covered the learners from the undergraduate and postgraduate levels in 65:35 ratios, respectively. The counselling support was also provided to the learners by the faculty in the IGNOU Headquarters, particularly to the learners of undergraduate and postgraduate computer science programmes and other courses such as Bachelor of Education, Masters in Psychology, Hindi, M Com, Diploma in Dairy Technology etc. The course selection for the online counselling was learners' enrolment in a particular course, availability of ACs and specific request from the learners. Though the learners from all the streams were covered yet, most learners $(75 \%)$ were from the humanities and social sciences.

Tools employed: A questionnaire was designed and developed in Google form to elicit feedback from the learners enrolled in the January 2020 session under IGNOU RC Chandigarh, an operational area spanning the UT Chandigarh and parts of the states of Punjab and Haryana.

Administration of the tool: The learners' response obtained through the Google form by providing a link sent to the learners through email and SMSs. The link also sent through repeat SMSs and emails to remind the learners to submit the responses.

Design of the questionnaire: A questionnaire designed to collect information about learners' demographic and socio-economic profile, along with the details regarding the availability of electronic gadgets such as desktop, laptop, smartphone and problems faced by them in uniform accessibility of the Internet. The questions framed to obtain feedback on a five-point Likert scale on the following aspects:

(1) Learners' awareness about the conduct of e-counselling sessions and their participation in such sessions.

(2) Source of information/awareness about the organisation and conduct of the ecounselling sessions.

(3) Problems encountered, if any, attending the counselling sessions about the availability of electronic gadgets, Internet access and intermittent Internet disturbances.

(4) Quality of the e-counselling sessions.

(5) Clarity in content delivery by the academic counsellors.

(6) Whether the e-counselling sessions met their study requirement during the lockdown.

(7) Comparison of face-to-face counselling with e-counselling.

(8) Conduct of the e-induction meeting.

(9) Usefulness of e-counselling sessions for preparing the assignments.

(10) Whether the message conveyed through induction meetings met the distance learners' expectation to pace the learning.
E-counselling support during COVID-19 pandemic 
AAOUJ

16,2

\section{Data analysis and interpretation}

\subsection{Learner profile and information on various attributes that influence e-counselling}

The profile of learners who responded to the questionnaire, in respect of various attributes, has been presented (Table 1):

Analysis of respondents' profile reveals that $42.59 \%$ of respondents pursued undergraduate programmes, $36.6 \%$ postgraduate, $15.2 \%$ diploma and $3.6 \%$ certificate programmes. Considering the total enrolment share, the proportion of respondents pursuing a PG diploma was only $1.6 \%$, which was significantly low. The demographic profile reveals that $53.5 \%$ of respondents were from the urban areas and $46.5 \%$ from the rural area, which is contrary to the enrolment proportion of learners from urban and rural areas, respectively. Similarly, $53.3 \%$ of respondents were male, and $46.5 \%$ were female. Thus, there was no significant variation in the representation of respondents concerning background and sex.

\subsection{Availability and accessibility of electronic gadgets}

Learners' response to essential attributes, including electronic devices, information about ecounselling sessions, and participation in the counselling sessions also collected and analysed. Analysis of the media's used to provide information to the learners reveals that $47.2 \%$ of respondents received information regarding e-counselling through SMSs. It is pertinent to note that frequent SMSs sent to the learners to participate in the e-counselling sessions. On the other hand, 33.9\% of respondents reported that they got information through email. Similarly, $15.1 \%$ of respondents received information through the RC Facebook page. However, the proportion of respondents who received information through $\mathrm{RC}$ and IGNOU Hqtrs websites was insignificant. It is pertinent to mention that SMS was the most effective method of information dissemination than other means.

Several e-platforms such as Webex, Microsoft team, zoom, Google meet, GoToMeeting etc. used during lockdown for various purposes. However, RC used only three platforms for organising e-counselling sessions, i.e. zoom, Google meet and RC FB page. Feedback from the respondents also collected on the suitability of different platforms used to conduct ecounselling sessions (Table 2 and Figure 1). The platforms used for e-sessions have one or the other limitations; for instance, the zoom meeting is allowed for a limited time and has a problem with data security. Facebook has a broader reach, but any FB friend can join it. Such participants may create nuisance during the live session. Thus, the selection of a platform is essential for enhancing learning; therefore, Google meet was considered a suitable platform for interaction as it could accommodate up to 250 participants.

Table 1.

\begin{tabular}{llrr}
\hline Attributes & & No & $\%$ \\
\hline \multirow{2}{*}{ Background } & Rural & 207 & 46.5 \\
& Urban & 238 & 53.5 \\
& Total & 445 & 100.0 \\
Sex & Male & 208 & 46.7 \\
& Female & 237 & 53.3 \\
& Total & 445 & 100.0
\end{tabular}




\begin{tabular}{|c|c|c|c|c|}
\hline Variables & & No & $\%$ & E-counselling \\
\hline \multirow[t]{6}{*}{ Sources of information regarding e-counselling } & email & 151 & 33.9 & COVID-19 \\
\hline & SMS & 210 & 47.2 & mondomis \\
\hline & RC FB Page & 67 & 1,501 & pandemı \\
\hline & $\mathrm{RC}$ website & 9 & 2.0 & \\
\hline & HQ website & 8 & 1.2 & \\
\hline & Total & 445 & 100.0 & 151 \\
\hline \multirow[t]{4}{*}{ Electronic device used } & Smartphone & 387 & 88.6 & \\
\hline & Laptop & 43 & 9.8 & \\
\hline & Desktop & 7 & 1.6 & \\
\hline & Total & 445 & 100.0 & \\
\hline \multirow{4}{*}{ Suitability of e-counselling platform } & FB page & 221 & 49.7 & \\
\hline & Zoom cloud App & 97 & 21.8 & \\
\hline & Meet.Google.com & 127 & 28.8 & \\
\hline & Total & 445 & 100.0 & \\
\hline \multirow[t]{5}{*}{ Problem-related to Internet } & Slow speed & 242 & 54.4 & \\
\hline & Intermittent break & 153 & 34.38 & \\
\hline & Problem with device & 43 & 9.7 & Essential attributes \\
\hline & Internet not available & 7 & 1.6 & for conducting \\
\hline & Total & 445 & 100.0 & e-counselling \\
\hline
\end{tabular}

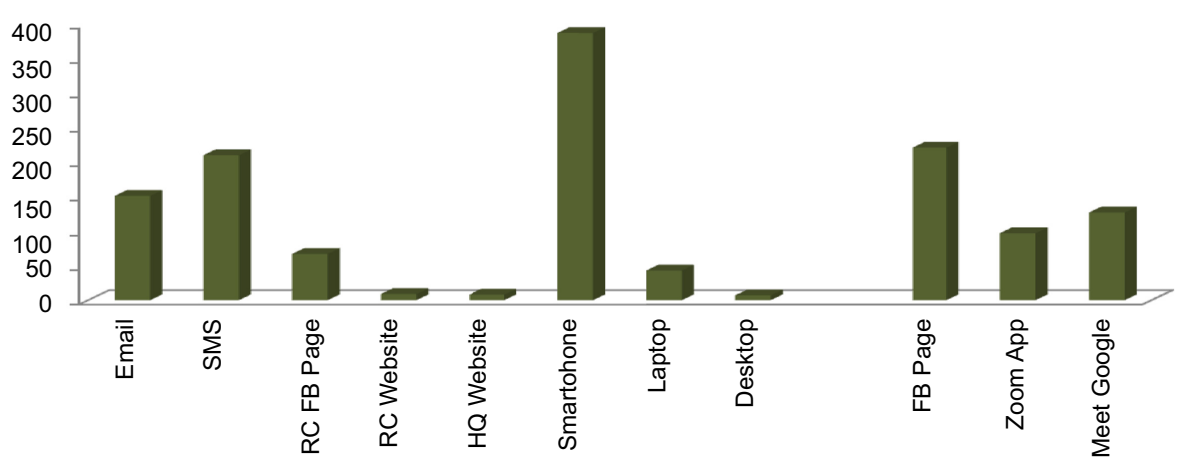

Figure 1. Feedback on information dissemination, device and platform

Analysis of the respondents' feedback on media preference revealed that $49.7 \%$ of respondents had their choice for FB page, followed by $28.8 \%$ Google meet. There have been several arguments on the use of a digital platform for online learning. Moore et al. (2018) argued that the students in India who have "access to a device might not have the digital skill to learn online effectively". An online learning ecosystem needs to be developed suitably in a country like India (Lynch, 2020). This argument is substantiated because, initially, only the top 100 universities were allowed by the University Grant Commission in India to offer online courses. Therefore, these factors need attention while adopting the online mode of academic counselling.

On the other hand, $54.4 \%$ of respondents reported that Internet speed was very slow; thus, there was discontinuity during the sessions. However, the respondents were happy to find the recorded version of sessions on the $\mathrm{RC}$ website and $\mathrm{FB}$ page. These efforts of $\mathrm{RC}$ appreciated by the learners who were even outside the jurisdiction of RC. For instance, Bala Krishan Puthiya Purayil, a student from Kerala, states, "I think the best way to get classes conducted by $\mathrm{RC}$ is to make available the recorded content on the RC Facebook page as done by RC. . .Chandigarh". Similarly, Sai Teja comments, "Chandigarh RC is uploading their recorded content on their RC FB page" regularly. Another vital feedback about the Internet was the intermittent break in Internet accessibility. $34.38 \%$ of respondents reported that there was an 
AAOUJ 16,2

\section{2}

Table 3.

Learners' response to various attributes about e-counselling intermittent Internet break due to which they could not participate in the entire session. As discussed in the preceding section, the argument of several scholars stands to reason that the digital divide will create a considerable gap; therefore, the accessibility of online counselling session will not be uniform (Moore et al., 2018). Moreover, lack of the skills to handle the device will also jeopardise organising e-counselling sessions. Nonetheless, the finding reveals that only $9.7 \%$ (Table 2 ) of respondents faced the problem in handling the electronic gadgets due to lack of proper skill and first-time experience. Thus, the number of learners who have reported non-availability of the Internet for attending the e-counselling sessions was insignificant $(1.6 \%)$. Such a response could probably be attributed to the predominance of learners from semi-urban areas with relatively more access to electronic devices and the Internet.

\subsection{Attributes of e-counselling sessions}

Learners' feedback on the awareness regarding e-counselling sessions' reveals that $78 \%$ of respondents are aware of e-counselling sessions, and 64\% participated in the e-counselling sessions (Table 3). However, a considerable number of respondents $(36 \%)$ did not participate in the e-counselling sessions. Understanding the reasons for the reluctance of such a large number of learners will require further investigation. However, $61.1 \%$ of respondents reported that they encountered problems associated with the Internet, including slow speed and intermittent break. Moreover, "last-minute cramming in internet-based courses is rampant" (Figlio et al., 2013), which also influences learners' participation rate to a great extent.

It is also pertinent to note that $49.2 \%$ of respondents who participated in the e-counselling sessions also interacted with the ACs, and $69.2 \%$ reported that the e-counselling sessions were interactive (Table 3 and Figure 2). The interaction in the e-counselling could address the academic issues of the learners. The learners have given encouraging feedback regarding the replacement of f $2 \mathrm{f}$ counselling with e-counselling. In this context, $58.7 \%$ of respondents have expressed that f2f counselling replaced with e-counselling. Further, 83.8\% of respondents reported that IGNOU should organise more e-counselling sessions (Figure 3). The opinions of academics sharply divided on organising online counselling. It has been argued that the universities might "enjoy financial benefits with internet-based courses as the video lectures" once produced could be repeated in the subsequent sessions. However, favourable economies of scale are derived at the cost of the low level of interaction with the learners and compromising with the benefits of $\mathrm{f} 2 \mathrm{f}$ interaction (Figlio et al., 2013).

\begin{tabular}{|c|c|c|c|c|c|c|}
\hline \multirow[b]{2}{*}{ Variables } & \multicolumn{2}{|c|}{ Responses } & \multirow[b]{2}{*}{ Variables } & \multicolumn{2}{|c|}{ Responses } & \multirow[b]{2}{*}{ Total } \\
\hline & Yes $(\%)$ & No $(\%)$ & & Yes $(\%)$ & No $(\%)$ & \\
\hline Awareness & & & Interactivities & & & \\
\hline $\begin{array}{l}\text { About e-counselling } \\
\text { sessions }\end{array}$ & $347(78)$ & $78(22)$ & $\begin{array}{l}\text { Participation in } \\
\text { e-counselling sessions }\end{array}$ & $285(64)$ & $160(36)$ & $445(100)$ \\
\hline $\begin{array}{l}\text { Participation in } \\
\text { induction meeting }\end{array}$ & $245(55.1)$ & $200(44.9)$ & $\begin{array}{l}\text { Interaction in } \\
\text { e-counselling sessions }\end{array}$ & $308(69.2)$ & 137 (30.8) & \\
\hline $\begin{array}{l}\text { Support for preparation } \\
\text { of TEE }\end{array}$ & $305(69.21)$ & 140 (31.4) & Took part in Interaction & $219(49.2)$ & $226(50.8)$ & $445(100)$ \\
\hline Usefulness & & & Challenges & & & \\
\hline $\begin{array}{l}\text { The usefulness of } \\
\text { e-counselling sessions } \\
\text { for preparation of } \\
\text { assignments }\end{array}$ & $299(67.2)$ & $146(32.8)$ & $\begin{array}{l}\text { Problem-related to } \\
\text { Internet }\end{array}$ & 272 (61.1) & $173(38.9)$ & $445(100)$ \\
\hline $\begin{array}{l}\text { Demand for more e- } \\
\text { counselling sessions }\end{array}$ & $373(83.8)$ & $72(16,2)$ & $\begin{array}{l}\text { Recommendation } \\
\text { Face to face counselling } \\
\text { to be replaced by } \\
\text { e-counselling }\end{array}$ & $261(58.7)$ & $184(41.3)$ & $445(100)$ \\
\hline
\end{tabular}


5.4 Feedback on e-induction meetings

Learners' feedback was also obtained on their participation in the induction meetings, and $55.1 \%$ reported that they participated in the induction meeting (Table 3). A considerable proportion of respondents $(44.9 \%)$ could not participate in the induction meeting. Still, most of them reported that they could view the recording of the induction meetings uploaded on the $\mathrm{RC} F B$ page and website. The meeting's reach was for $1.6 \mathrm{~K}$ learners with 220 comments and 813 engagements. A similar response recorded in the successive induction meetings organised to cover the remaining learners.

Learners' response to the online induction meetings indicates that most of them $(91.9 \%)$ appreciated the efforts to organise the e-induction meeting to set the pace for learning during the lockdown, and more than one-third of the respondents $(35.0 \%)$ have reported that conducting e-induction meetings was a rewarding experience. Similarly, $27 \%$ of respondents believed that probably conducting e-induction meetings was a welcome initiative. On the other hand, $28 \%$ of respondents were neutral and reported that it was helpful for them. The proportion of respondents who have given negative feedback was insignificant, with $6.1 \%$ poor and $3.6 \%$ very poor (Table 4 ). However, the input is considered a constructive measure to sustain efforts in the future.

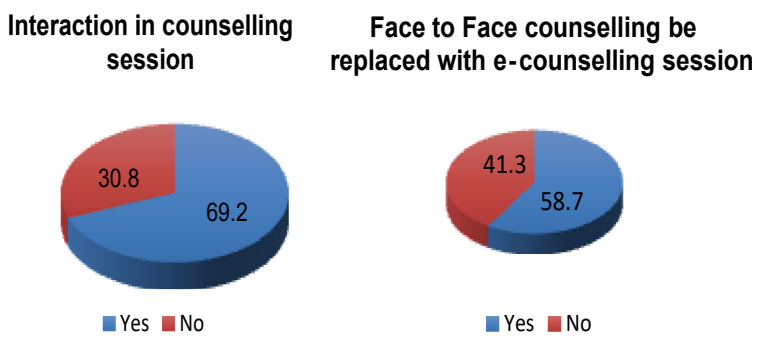

Requirement of more ecounselling sesions

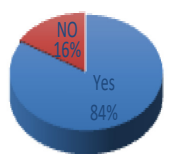

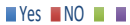

Percent learners participation in e- counselling sessions

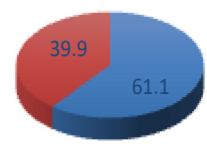

Yes No
E-counselling support during COVID-19 pandemic

153
Figure 2.

Analysis of feedback on attributes of ecounselling
Figure 3.

Preference for ecounselling sessions

\begin{tabular}{lcccccc}
\hline & & Very & & & Very & Total \\
Variables & Excellent & good & Fair & Poor & poor & T \\
\hline $\begin{array}{l}\text { Effectiveness of induction meeting } \\
\text { to pace the learning }\end{array}$ & $156(35)$ & $120(27)$ & $125(28.1)$ & $28(6.1)$ & $16(3.6)$ & $445(100.0)$ \\
$\begin{array}{l}\text { Rating for the information provided } \\
\text { in the e-induction meetings }\end{array}$ & $97(21.8)$ & $178(40)$ & $130(29.2)$ & $27(6.1)$ & $13(2.9)$ & $445(100.0)$
\end{tabular}

Note(s): Figures in the table denotes number and percentage in brackets

Table 4 .

Learners' feedback on the content and methodology of ecounselling sessions 
AAOUJ 16,2

\section{4}

Table 5.

Learners feedback on the effectiveness of e-counselling

The learners also asked to rate the induction meetings' information on a five-point Likert scale. On the other hand, $21.8 \%$ of responses were for the highest rating with excellent feedback, followed by $40 \%$ very good and $29.2 \%$ fair. Thus, most of the respondents $(90 \%)$ were satisfied with the information provided during e-induction meetings. On the other hand, about $10 \%$ of respondents have a poor rating for the information provided in the induction meetings,' with $6.1 \%$ poor and $2.1 \%$ very poor (Table 5 and Figure 4 ).

\subsection{Learners' feedback on the effectiveness of e-counselling}

The respondent's feedback received on various attributes to assess the efficacy of the ecounselling sessions, and the analysis of the same presented below (Table 5):

The analysis of respondents' feedback on the Likert five-point scale revealed that $36.9 \%$ of respondents definitely agree with e-counselling sessions as it met their study requirements. On the other hand, $21.8 \%$ of respondents reported that the e-counselling sessions probably met their study requirements. Similarly, $22.5 \%$ of respondents said that it has possibly met the study requirements. An online education system using "interactive multimedia" can help the learners to understand the learning content better and enhance achievement level and "learning performance comparable" to f2f learning (Zhang and Zhou, 2003). However, 18.9\% of respondents have given negative feedback, $11.5 \%$ of them were moderate in recording negative feedback, and $7.4 \%$ of respondents have reported that e-counselling efforts have definitely not met the learning requirements. It certainly warrants the attention of academic support providers.

\begin{tabular}{|c|c|c|c|c|c|c|}
\hline Variables & Definitely & Probably & Possibly & $\begin{array}{c}\text { Possibly } \\
\text { Not }\end{array}$ & $\begin{array}{c}\text { Definitely } \\
\text { Not }\end{array}$ & Total \\
\hline $\begin{array}{l}\text { e-Counselling sessions met } \\
\text { study requirements }\end{array}$ & 164 (36.9) & 97 (21.8) & $100(22.5)$ & 51 (11.5) & $33(7.4)$ & $445(100.0)$ \\
\hline Enhancement of study skill & $172(38.7)$ & 95 (21.3) & $116(26.1)$ & $36(8.1)$ & $26(5.8)$ & $445(100.0)$ \\
\hline $\begin{array}{l}\text { Rating for the content } \\
\text { delivered by the academic } \\
\text { counsellors }\end{array}$ & 95 (21.3) & 166 (37.3) & 136 (30.6) & $31(7.0)$ & $17(3.8)$ & $445(100.0)$ \\
\hline $\begin{array}{l}\text { Rating for the methodology } \\
\text { used by the academic } \\
\text { counsellors }\end{array}$ & 88 (19.9) & $163(36.6)$ & 150 (33.7) & $32(7.7)$ & $12(2.7)$ & $445(100.0)$ \\
\hline $\begin{array}{l}\text { Learners feedback on the } \\
\text { initiative during the } \\
\text { lockdown }\end{array}$ & $111(24.9)$ & $170(38.2)$ & $125(28.1)$ & 28 (6.3) & $11(2.5)$ & $445(100.0)$ \\
\hline
\end{tabular}

Figure 4.

Learners rating on effectiveness of e-counselling
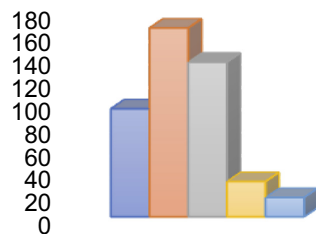

Rating for the content delivery

口Definitely $\square$ Probably
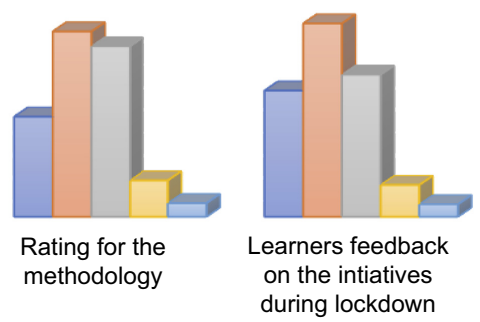

$\square$ Possibly $\square$ Possibly Not $\square$ Definitely Not 
An attempt made to establish a relationship between the conduct of e-counselling sessions and enhancement of learning skills. Interestingly, $38.7 \%$ of respondents have reported that ecounselling sessions have definitely enhanced their study skills. Whereas $21.3 \%$ of respondents believed that it probably enhanced the study skills, $26.4 \%$ of respondents have reported that it possibly enhanced the study skills. The feedback of $8.1 \%$ of respondents was possibly not, and $5.8 \%$ definitely not. However, most of the respondents reported that ecounselling sessions helped enhance their study skills and the finding supported by researchers in their empirical studies (Kirby, 1999; Roper, 2007). Though the proportion of learners who have given negative feedback is insignificant, further research will improve their efforts to provide e-counselling support.

An attempt also made to involve $\mathrm{ACs}$ with rich experience and exposure to deliver content to the learners using smart classes. A meeting was held with the academic counsellors to discuss the nature of e-counselling sessions to be organised. The focus should be on delivering the content as per IGNOU's counselling norms rather than addressing learners' anxiety. In the Initial one hour, course content discussed, followed by half an hour on interaction, and the uniform pattern observed across all e-counselling sessions.

While analysing the learners' feedback on the content delivered through e-counselling sessions, $21.3 \%$ reported, it was excellent. On the other hand, $37.3 \%$ of respondents (Table 5) confirmed that the delivered content was very good. However, $30.6 \%$ of respondents were neutral in their approach and rated the content as fair. However, $7 \%$ of respondents rated content poor and $3.8 \%$ very poor. Data analysis reveals that the majority of the learners were satisfied with the content delivered in e-counselling sessions. An attempt also made to collect feedback on the methodology of e-counselling sessions, such as sharing PPT, video etc., for making presentations effective. Thus, $19.9 \%$ of respondents reported that the methodology used for e-counselling sessions was excellent, and $36.6 \%$ responded it was very good and $33.7 \%$ fair. On the other hand, $7.7 \%$ of respondents rated it poor and 2.7 very poor (Table 5 Figure 4).

The objective of organising e-counselling sessions was to ensure that the learners' learning requirement is met during the lockdown to continue their efforts to prepare assignments and start preparation for the Term End Examination. Accordingly, learners' feedback obtained on the clarity in delivering the topic by the ACs and the data analysis presented below (Table 6 and Figure 5):

As far as clarity regarding content is concerned, $24 \%$ of respondents have reported a high level of clarity in explaining the content of the topic by the ACs in e-counselling sessions. Similarly, $42.2 \%$ of respondents reported that the ACs had explained the topic with clarity. However, $28.1 \%$ of learners were neutral in their approach and reported that they could not say whether the ACs has explained the topic with clarity. Nevertheless, two-thirds of respondents $(66.2 \%)$ reported that ACs explained the subject with clarity. On the other hand, $2.9 \%$ of respondents have given poor rating under this topic, with $2.7 \%$ very poor; thus, the proportion of respondents who have negative feedback is very small and insignificant.

The interaction with the learners is equally vital in the e-counselling sessions to gauge their interest and satisfaction level (Kurucay and Inan, 2017). Accordingly, an attempt was made to collect the learners' feedback on the interaction in the e-counselling sessions. $18.2 \%$

\begin{tabular}{lcccccc}
\hline Variables & Very clear & Clear & Can’t say & Poor & Very poor & Total \\
\hline AC explain the topic with clarity & $107(24)$ & $188(42.2)$ & $125(28.1)$ & $13(2.9)$ & $12(2.7)$ & $445(100.0)$ \\
Clarity at the level of interaction & $81(18.2)$ & $177(39.8)$ & $152(34.2)$ & $26(5.8)$ & $9(2)$ & $445(100.0)$
\end{tabular}

Note(s): Figures in the table denotes number and percentage in brackets
E-counselling support during COVID-19 pandemic
Table 6. Feedback of the learners on the clarity of the topic and interaction 
AAOUJ 16,2

\section{6}

Figure 5.

Learners' feedback on clarity in understanding the content of respondents reported that the level of interaction with ACs was very effective, useful and clear, $39.8 \%$ of respondents realised that the level of interaction was precise, and $34.2 \%$ of respondents were neutral while rating the clarity in interaction level. The importance of clarity in content delivery dealt with in several studies. Hrastinski et al. (2010) argued that in online course delivery, the interaction level sustains the interest and motivation of the learners. On the other hand, $5.8 \%$ of respondents have a poor rating for clarity in interaction, with $2.0 \%$ very poor. However, most of the respondents were satisfied with the level of interaction in e-counselling sessions with ACs. The proportion of learners who gave negative feedback is insignificant, considering the size of the sample. However, such feedback could be regarded as important and would undoubtedly help to improve the e-counselling sessions.

Analysis of learners' feedback on the university's initiative to organise the e-counselling sessions revealed that $24.4 \%$ of respondents realised it was definitely an excellent initiative to organise e-counselling sessions during the lockdown (Table 5). $38.2 \%$ of respondents reported that probably it was an initiative that helped the learners. Similarly, $28.1 \%$ of respondents expressed that possibly it was a good effort. It is interesting to note that more than $90 \%$ of respondents have supported the university's efforts to organise the e-counselling sessions during the lockdown. The learners' positive inclination towards online counselling also studied in several research studies (Kirby, 1999; Zhang and Zhou, 2003). Only 8.8\% of learners have given negative feedback, and further investigation will help to determine their dissatisfaction.

\section{Findings and recommendations of the study}

In the preceding section, we analysed the feedback of the learners. The findings of the same synthesised and presented next:

(1) The variation in the male-female and rural-urban composition of respondents was not very significant. The proportion of urban respondents $(53.8 \%)$ and female respondents $(53.2 \%)$ was marginally higher.

(2) Although the learners used different electronic gadgets such as laptops, desktop and smartphones, most of the respondents $(88.6 \%)$ used smartphones to attend ecounselling sessions organised during the lockdown.

(3) SMS was a vital medium (47.2\%) for disseminating information to the learners regarding e-counselling sessions followed by email (33.9\%). However, $15.9 \%$ of respondents obtained information through the $\mathrm{RC} F B$ page. The proportion of respondents who used IGNOU Hqtrs and $\mathrm{RC}$ websites for getting information for e-counselling sessions was insignificant.

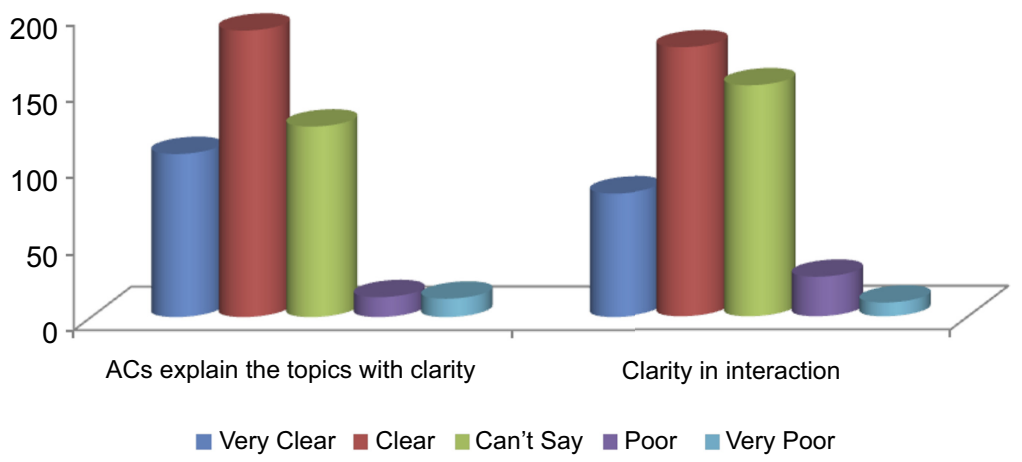


(4) The majority of the learners $(49.7 \%)$ have preferred FB page for attending ecounselling sessions over Google meet and Zoom platforms.

(5) Although most learners appreciated the efforts of $\mathrm{RC}$ to organise e-counselling sessions, slow Internet speed (54.4\%) and intermittent Internet break $(34.38 \%)$ ) were the significant challenges for the smooth conduct of e-counselling sessions. The proportion of learners who faced problem in handling electronic gadgets was $9.7 \%$ which was relatively low.

E-counselling support during COVID-19 pandemic

(6) The majority of the respondents $(78 \%)$ were aware of the university's initiatives to organise e-counselling sessions, and $64 \%$ of them participated in the e-counselling sessions.

(7) Almost three-fifth $(58.7 \%)$ of respondents reported that face-to-face counselling be replaced with e-counselling sessions. $69.2 \%$ of respondents reported that ecounselling sessions were interactive, and $64.2 \%$ participated in the interaction.

(8) It is also encouraging to note that $83.8 \%$ of respondents reported that the university should organise more e-counselling sessions to fulfil their learning pursuit.

(9) Similarly, $67.2 \%$ of respondents reported that e-counselling sessions provided useful input, helped to prepare assignments, and $69.21 \%$ reported the usefulness of inputs for preparing the Term End Examination. Among these learners, 36.6\% reported that it definitely proved valuable input, and $21.8 \%$ reported that the input was possibly useful. University should undertake more online counselling sessions in future by strengthening infrastructures at its RCs. However, $22 \%$ of respondents were not clear in providing feedback. Approximately one-fifth of respondents were not satisfied with the input provided through e-counselling sessions. This feedback certainly warrants attention and implies more focus of the university on monitoring of e-counselling sessions.

(10) A significantly higher proportion of respondents (60\%) reported that e-counselling sessions enhanced their study skills. However, $13.9 \%$ of respondents believed that ecounselling support was not adequate.

(11) It is also encouraging to note that $63.1 \%$ of respondents appreciated the university's efforts to organise e-counselling sessions during the lockdown. Among such respondents, only $8.8 \%$ of learners have negative feedback which could be attributed to electronic gadgets, uniform access to the Internet, Internet speed and handling electronic devices.

(12) The majority of the respondents (58.6\%) also appreciated the content used by the ACs. However, there was an insignificant proportion of respondents $(10.8 \%)$ who were not satisfied with the e-content used during the lockdown. On the other hand, a similar proportion of learners appreciated the methodology used by the ACs.

(13) The majority of the learners reported that the ACs explained the topic with clarity, and the level of clarity was very high during the interaction. Although the learners were satisfied with the input provided by ACs, however, the panel of ACs prepared at the RC level, and capacity building programme for handling online counselling session effectively is essential.

(14) The learners also appreciated the information provided in the induction meeting, and $60 \%$ of them reported that the information was beneficial. 
AAOUJ

16,2

\section{8}

(15) Suitable infrastructure should be developed at $\mathrm{RC}$ for the recording and dissemination of online content effectively.

(16) Capacity building of academics posted at the RCs is essential on various aspects of ecounselling and content delivery for effective online and digital education.

(17) It is also essential to re-visit the existing part-time staffing pattern at the LSCs in the context of lesser workload due to online course delivery; this will reduce the cost substantially, besides conducting inter and intra-region online counselling.

\section{Conclusion}

This empirical research study analysed the respondents' feedback on various issues about ecounselling sessions organised during the lockdown. Although most of the respondents appreciated the efforts to provide academic support, nearly one-tenth respondent was not satisfied with various attributes. The dissatisfaction probably could be due to device, Internet connectivity, or the delivered academic inputs and interaction level. Since academic support linked with performance, the findings of the study certainly indicate that more sustained efforts are required to address the academic issues of the learners while providing online classes. Therefore, a better monitoring mechanism would undoubtedly help to make academic support services more effective in sustaining their interest in learning pursuit. A shift to online academic support also warrants the capacity building of ACs through training and orientation for effectively managing online learning so that a robust and sustainable educational system put in place.

We may conclude that these efforts to provide e-counselling sessions motivated the learners during the lockdown and helped to sustain their interest in their learning pursuits and minimise the unrest and anxiety. However, the critics' argument that the ERT support provided to the learners during the lockdown will quickly be forgotten by the learners once normalcy returns also warrants in-depth investigation in time to come. Nonetheless, specific issues include the digital divide, the problem of devices, uniform Internet accessibility and intermittent break in Internet supply that need to be addressed at the policy level to make ecounselling support effective besides ensuring social interaction (Mayer and Richard, 2012). Finally, we may conclude that the learner's feedback was encouraging and provides ample scope for further improvement and gives an option to replace f2f counselling with online and digital education. However, any decision for this paradigm shift would require more in-depth empirical studies with a more significant segment of learners, besides creating suitable infrastructure by assessing the prerequisites for programme delivery and capacity building. Conducting online counselling will undoubtedly be cost-effective (Figlio et al., 2013) as it favours the ODL institutions and the universities and deprives the learners of the benefit of $\mathrm{f} 2 \mathrm{f}$ interaction. Therefore, a bend of both $\mathrm{f} 2 \mathrm{f}$ and online counselling can be a more appropriate option.

\section{References}

Anderson, T. and Dron, J. (2011), "Learning technology through three generations of technologyenhanced distance education pedagogy”, European Journal of Open, Distance and E-Learning, Vol. 12 No. 3, pp. 80-97, available at: http://www.eurodl.org/?article=523\ (accessed 15 July 2020).

Bayrak, F., Tibi, M.H. and Altun, A. (2020), "Development of online course satisfaction scale", Turkish Online Journal of Distance Education TOJDE, Vol. 21 No. 4, pp. 110-123, available at: https:// dergipark.org.tr/en/download/article-file/1321239 (accessed 15 December 2020). 
Bozkurt, A. and Sharma, R.C. (2020), "Emergency remote teaching in a time of global crisis due to coronavirus pandemic", Asian Journal of Distance, Vol. 15 No. 1, pp. i-vii, available at: https:// www.asianjde.org/ojs/index.php/AsianJDE/article/view/447 (accessed 10 August 2020).

Britto, M. and Rush, S. (2013), "Developing and implementing comprehensive student support services for online students", Journal of Asynchronous Learning Networks, Vol. 17, pp. $29-42$.

Chen, S.J. (2007), "Instructional design strategies for intensive online courses: an objectivistconstructivist blended approach”, Journal of Interactive Online Learning, Vol. 6 No. 1, pp. 72-86.

Clark, C., Strudler, N. and Grove, K. (2015), "Comparing asynchronous and synchronous video vs textbased discussions in an online teacher education course", Online Learning, Vol. 19 No. 3, pp. 48-69.

Dimri, A.K. (2018), "Analysis of the perception of successful learners on student support services: Indian experience”, Online International Interdisciplinary Research Journal, Vol. 08 No. 01, pp. 118-132, available at: https://oiirj.org/oiirj/blog/2018/01/01/volume-08-issue-01-jan-feb-20182/ (accessed 18 August 2020).

Dimri, A.K. (2020), "Learners feedback on IGNOU e-content material: a corona lockdown survey", Education Tech: Online Journal of Distance Education, No. 2020-00010, pp. 1-13, available at: http://www.edutech.net.in/Articles/2020/Art00010.pdf (accessed 23 August 2020).

Figlio, D., Rush, M. and Yin, L. (2013), "Is it live or is it internet? Experimental estimates of the effects of online instruction on student learning", Journal of Labor Economics, Vol. 31 No. 4, pp. 763-784.

Golden, C. (2020), "Remote teaching: the glass half-full", Educause Review, available at: https:/er. educause.edu/blogs/2020/3/ remote-teaching-the-glass-half-full (accessed 21 August 2020).

Gorge, L.J. and Gaea, L. (2016), "Going the distance with online education”, Online Education Review of Educational Research, Vol. 76 No. 4, pp. 567-605, available at: https://leedsprimoexlibrisgroup. $\mathrm{com} /$ discovery/fulldisplay?docid $=$ cdi_proquest_journals214115678\& context $=$ PC\&vid $=$ LEE_ INST:VU1\&lang $=$ en\&search_scope $=($ accessed 11 December 2020).

Hodges, C., Moore, S., Barb, L.B., Trust, T. and Bond, A. (2020), "The difference between emergency remote teaching and online learning", available at: https://er.educause.edu/articles /2020/3/thedifference-between-emergency-remote-teaching-and-online-learning (accessed 28 July 2020).

Hrastinski, S., Keller, C. and Carlsson, S.A. (2010), "Design exemplars for synchronous e-learning: a design theory approach", Computers and Education, Vol. 55, pp. 652-662.

Kirby, E. (1999), "Building interaction in online and distance education courses", Conference Proceedings, SITE '99: Society for Information Technology and Teacher Education International Conference, San Antonio, TX.

Kriger, T.J. (2001), A Virtual Revolution: Trends in the Expansion of Distance Education, Federation of Teachers, Washington, DC.

Kurucey, M. and Inan, F.A. (2017), "Examining the effects of learner-learner interactions on satisfaction and learning in an online undergraduate course", Computers and Education, Vol. 115 No. 12, pp. 20-37.

Lister, M. (2014), "Trends in the design of e-learning and online learning”, Journal of Online Learning and Teaching, Vol. 10 No. 4, pp. 671-680.

Lynch, M. (2020), "E-Learning during a global pandemic", Asian Journal of Distance Education, Vol. 15 No. 1, pp. 189-195, doi: 10.5281/zenodo3881785 (accessed 20 July 2020).

Mayer, S.E. and Richard, E. (2012), "Five facets of social presence in online distance education", Computers in Human Behavior, Vol. 28 No. 5, pp. 1738-1747, available at: https://www. sciencedirect.com/science/article/pii/S0747563212001185?via\%3Dihub (accessed 16 December 2020).

Moore, M.G. (1989), “Three types of interaction”, American Journal of Distance Education, Vol. 3 No. 2, doi: 10.1080/08923648909526659 (accessed 9 June 2020).
E-counselling support during COVID-19 pandemic 
AAOUJ

16,2

160

Moore, M. (1993), "Theory of transactional distance", in Keegan, D. (Ed.), Theoretical Principles of Distance Education, Routledge, London, pp. 22-38.

Moore, M.G. and Kearsley, G. (2005), Distance Education: A Systems View, Wadsworth, New York, NY.

Moore, R., Vitale, D. and Stawinoga, N. (2018), "The digital divide and educational equity: a look at students with very limited access to electronic devices at home", Insights in Education and Work ACT Center for Equity in Learning, pp. 1-10, available at: https://www.researchgatenet/ publication/337991148_The_Digital_Divide_and_Educational_Equity_A_Look_at_Students with _ Very _Limited_Access_to_Electronic_Devices_at_Home (accessed 31 July 2020).

Olcott, D. (2020), "Going online: life in the online fast lane or so the story goes", Asian Journal of Distance Education, Vol. 15 No. 2, pp. 180-184, available at: https://www.asianjde.org/ojs/index .php /Asian J DE/article/ view/449/302 (accessed 12 December 2020).

Reiser, R.A. and Dempsey, J.V. (2012), in Erlbaum, N.J. (Ed.), Trends and Issues in Instructional Design and Technology, Upper Saddle River.

Roper, A.R. (2007), "How students develop online learning skills", Educause Quarterly, Vol. 30 No. 1, pp. 62-65.

Tait, A. (2004), "On institutional models and concepts of student support services: the case of the Open University UK", in Brindle, J.E., Walti, C. and Richter, O.Z. (Eds), Learner Support in Open, Distance and Online Learning Environment, Oldenburg, pp. 283-293.

Tait, A. (2014), "From place to virtual space: reconfiguring student support for distance and e-learning in the digital age", Open Praxis, Vol. 6 No. 1, pp. 5-16, available at: https://files.eric.ed.gov/ fulltext/ EJ1076777.pdf (accessed 11 July 2020).

Thorpe, M. (2002), "Rethinking learner support: the challenge of collaborative online learning", Open Learning, Vol. 17 No. 2, pp. 105-119.

Watts, L. (2016), "Synchronous and asynchronous communication in distance learning: a review of the literature", Quarterly Review of Distance Education, Vol. 17 No. 1, pp. 23-32.

Woody, T. (1999), "Ivy online", The Standard, available at: http://www.thestandard.com/article/ display/0\%2C1151\%2C00.htm (accessed 18 November 2020).

Yamagata-Lynch, L.C. (2014), "Blending online asynchronous and synchronous learning", The International Review of Research in Open and Distributed Learning, Vol. 15 No. 2, pp. 189-212.

Zhang, D. and Zhou, L. (2003), "Enhancing e-learning with interactive multimedia", Information Resources Management Journal, available at: irmj.2003100101https://www.proquest.com/doc view/215883311?OpenUrlRefId=info:xri/sid:primo\&accountid=14664 (accessed 12 December 2020).

\section{Corresponding author}

Anil K. Dimri can be contacted at: akdimri@ignou.ac.in

For instructions on how to order reprints of this article, please visit our website:

www.emeraldgrouppublishing.com/licensing/reprints.htm

Or contact us for further details: permissions@emeraldinsight.com 